\title{
Stability of lactic acid bacteria and physico-chemical properties of pasteurized cow's and goat's milk
}

\author{
Nurfarhana Syed Malik, Mohd Nizam Lani, Fauziah Tufail Ahmad \\ School of Food Science and Technology, Universiti Malaysia Terengganu, Kuala Nerus 21030, Terengganu, Malaysia
}

* Corresponding author: fauziah.tufail@umt.edu.my

Article history

Received 28 December 2018

Revised 22 February 2019

Accepted 4 April 2019

Published Online 15 May 2019

\begin{abstract}
This study was done to determine the effect of pasteurization on the stability of lactic acid bacteria and its enzyme, and also its relation with physico-chemical properties in raw and pasteurized cow's and goat's milk. Most of the physico-chemical properties $(\mathrm{pH}$, protein, ash and fat) were highest in pasteurized goat's milk. The total viable count for plate count of the bacterial concentration was higher in both pasteurized cow's and goat's milk which were $2.48 \log \mathrm{CFU} / \mathrm{ml}$. This was followed by raw cow's milk (1.59 log CFU/ml) and raw goat's milk ( $0.65 \mathrm{log}$ CFU/ml). There was no yeast and mould detected in both raw and pasteurized cow's and goat's milk, respectively. Lactic acid bacteria (LAB) was found significantly higher in raw milk compared to pasteurized milk and higher macronutrients (proximate composition) could be considered as one of the factors for the survival of LAB. Interestingly, based on API ZYM assay kit result, there were nine different enzymes were detected in all samples which were leucine arylamidase, valine arylamidase, cystine arylamidase, trypsin, $\alpha$-chymotrypsin, naphthol-AS-BI-phosphohydrolase, $\alpha$-glucosidase, $\beta$-glucosidase and acid phosphatise. This result revealed that different types of lactic acid bacteria were detected in treated and non-treated milk samples produced by different animals.
\end{abstract}

Keywords: Milk, cow, goat, pasteurization, physico-chemical, lactic acid bacteria

\section{INTRODUCTION}

Pasteurization is one of the essential methods to destroy any pathogen in milk (Abdul Elrahman et al., 2013). Different types of pasteurization like Low Temperature Long Time (LTLT), High Temperature Short Time (HTST) and post pasteurization contamination play an important role in eliminating bacteria growth in milk, including beneficial bacteria (Dumalisile et al., 2005). Milk is one of the natural habitats that rich in nutrients for lactic acid bacteria growth (Delavenne et al., 2012). Lactic acid bacteria play an important role in dairy product especially milk. They have antimicrobial compounds that promote probiotic properties and can help to prolong their shelf life and nutritious component in milk (Khedid et al., 2009; Teshome, 2015). However, the temperature of pasteurization may affect the existence of lactic acid bacteria. The growth rate of lactic acid bacteria is totally counted on the available nutrients in the media (Hutkins and Nannen, 1993). When the nutrients are reduced with the pasteurization temperature (Tesfay et al., 2015), the growth of lactic acid bacteria may be affected as well. The different amounts of nutrients are also found in different animals such as goat and cow. Protein is high in cow's milk while goat's milk is higher in fat (FAO, 2013; Balthazaar et al., 2017). Lower nutrients in milk may lead to the different patterns of reduction in the beneficial effect of lactic acid bacteria in both milks. Lactic acid bacteria can also help in reducing the lactose intolerance (de Vrese et al., 2001). High temperature of pasteurization may reduce these effects too.

Pasteurization will affect the yeast and mould growth in the milk. It can extend the shelf life of milk by destroying almost all yeasts, moulds and common spoilage bacteria (Chipilev et al., 2016). Yeast and mould are more prominent to grow in a medium that has low $\mathrm{pH}$, moisture, temperature and high salt or sugar content which bacteria cannot compete (USDA, 2012). However, lactic acid bacteria are exception as they can grow in a high acid food which able to threaten the survival of yeast and mould in milk.

Water is the main component in all milks. Previous research has mentioned that minimal water activity content would support the growth of lactic acid bacteria (Troller and Stinson, 1981). Yeast and mould could also able to adapt in less water environment that enabled them to grow more (Brock and Madigan, 1986). Lactic acid bacteria would able to inhibit the mould growth due the antifungal properties of the lactic acid bacteria that subsequently could control the production of yeast and mould (Dalie et al., 2010; Blagojev et al., 2012).

Lactic acid bacteria is classified to synthesize a diverse type of enzyme which may influence the composition in food (Patel et al., 2013). Enzyme that found in the milk is not easily presented for digestibility of milk (Claeys et al., 2013). The activity of enzyme is mostly affected by the temperature, $\mathrm{pH}$, and presence of substrate, activators and inhibitors. Enzyme is mostly inactive at pasteurization condition due to long treatment with high temperature. However, not all enzymes will be destroyed during the pasteurization process. Many of these enzymes are remained active even after the heat treatment of milk which also may be related with the presence of lactic acid bacteria in pasteurized milk (Samarzija et al., 2012).

\section{EXPERIMENTAL}

\section{Sample collection}

This experiment was conducted in Universiti Malaysia Terengganu. 
Milk samples were collected at Marang, Terengganu and Veterinary Laboratory, Kelantan. After the collection of the samples, they were then separated into three different analyses which were physicochemical, microbiological status and lactic acid bacteria detection. The remaining samples were kept in freezer at $\left(-20^{\circ} \mathrm{C}\right)$ until required.

\section{Physico-chemical properties}

pH

$\mathrm{pH}$ value for each sample was measured using $\mathrm{pH}$ meter. Replication was done to obtain an accurate reading of $\mathrm{pH}$ for the samples.

\section{Chemical analysis}

Chemical analysis was carried out using AOAC (2000) method. Moisture content was analyzed using standard method while protein content was determined by using Kjedahl method. Ash content determination was done by using dry ashing method. Fat content was analyzed using Soxhlet dry extraction.

\section{Microbiological analysis}

A total of $25 \mathrm{~g}$ of milk sample was homogenized with $225 \mathrm{ml}$ of buffered peptone water aseptically. A serial dilution was done up to $10^{-8}$ using buffered peptone water and $0.1 \mathrm{ml}$ of the dilution was spread on Plate Count Agar (PCA) plate and potato dextrose agar (PDA), respectively. The prepared PCA was incubated at $37^{\circ} \mathrm{C}$ for $24 \mathrm{~h}$ while PDA was kept for 5 days at room temperature.

\section{LAB identification in milk}

Milk sample $(25 \mathrm{~g})$ was homogenized in $225 \mathrm{ml}$ of buffered peptone water. Then, $1 \mathrm{ml}$ of homogenized sample was added into $9 \mathrm{ml}$ of Man Rogosa Sharpe (MRS broth). This step was repeated for every sample. These samples were incubated at $30^{\circ} \mathrm{C}$ for 24 to $48 \mathrm{~h}$ in anaerobic condition. A serial dilution was done up to $10^{-8}$ using saline solution and $0.1 \mathrm{ml}$ of final dilution was pipetted and spread on MRS agar. The prepared petri dishes were incubated at anaerobic condition for 2 days.

\section{API ZYM}

The identification and confirmation of lactic acid bacteria (LAB) were analyzed using API ZYM (BioMerieux, France). API ZYM is a system that able to identify enzyme that has been applied by total 81 bacteria that belong to several species. The LAB presence in milk could be identified by the enzymes produced which were alkaline phosphatase, esterase, esterase lipase, lipase, leucine arylamidase, valine arylamidase, cystine arylamidase, trypsin, $\alpha$-chymotrypsin, aidphosphatase, naphthol-AS-BI-phosphohydrolase, $\alpha$-galactosidase, $\beta$ galactosidase, $\beta$-glucuronidase, $\alpha$-glucosidase, $\beta$-glucosidase, $\mathrm{N}$-acetyl$\beta$-glucosaminidase, $\alpha$-mannosidase or $\alpha$-fucosidase (Humble et al., 1977). The incubation box was spread with $5 \mathrm{ml}$ of distilled water into the honey comb wells of the tray to create humid atmosphere. The sample reference was analyzed by elongated flap of the tray. The strips were removed from the individual packaging and placed in the incubation box. $65 \mu \mathrm{L}$ of specimen was dispensed using micropipette each cupule. After inoculation, the plastic lid was placed on the tray and incubated for $4 \mathrm{~h}$ at $37^{\circ} \mathrm{C}$. Then a drop of ZYM A and ZYM B were added into each cupule and then kept in the dark for 5 minutes and under the light for about 10 seconds. This would help to eliminate any yellow colour which might be appeared in the cupules due to any excess of Fast Blue BB which has not reacted. The reactions were then graded depending on the intensity of colour compared with representations on a colour.

\section{Statistical analysis}

All obtained data was analyzed with two-way analysis of variance (ANOVA) using Minitab software to see the interaction between animals and pasteurization at $(\mathrm{p}<0.05)$. Pearson correlation coefficient was also used to determine the strength and direction of the linear relationship between all the variables.

\section{RESULTS AND DISCUSSION}

\section{Physico-chemical composition}

Physico-chemical contents of all samples were shown in Table 1. The $\mathrm{pH}$ of milk was within the normal range $(6.50 \pm 0.01$ to $6.77 \pm$ $0.01)$, indicating that there was no sign of mastitis infection in all samples (Ogola et al., 2007). There was significant interaction $(\mathrm{p}<0.05)$ between animals and pasteurization on the $\mathrm{pH}$ value of milk. The lower $\mathrm{pH}$ of goat's milk (pasteurized and non-pasteurized) was due to the presence and accumulation of carbon dioxide, phosphate, citrates, caesins and whey protein (Lai et al., 2016). In addition to that, the process of lactation period would also cause the milk to exhibit higher acidity than cow's milk (John, 1996). In general, pasteurized milk showed slightly higher $\mathrm{pH}$ value than raw milk. This was because raw milk was easily acidified than pasteurized milk (Caprita et al., 2014). The absence of pasteurization and delay in chilling after milking caused the increase in lipase activity by bacteria which led to lower $\mathrm{pH}$ value caused by their respiration (Wanjala et al., 2017). Increased level of acidity might influence the growth of lactic acid bacteria (LAB; Azizkhani and Tooryan, 2017) which would provide a medium for the growth of other microorganisms and LAB as well. This statement was supported with later result (Table 2) which showed that raw milk would give major contribution to the LAB growth. Even though pasteurized milk showed less acidity and appeared to be good quality, it might also contain bacteria that resulted in the spoilage to the milk (Anderson et al., 2011).

The moisture content in all samples was within range from $86.90 \pm$ $1.71 \%$ to $90.44 \pm 0.56 \%$. There was significant interaction $(\mathrm{p}<0.05)$ between animals and treatments. In raw milk, goat's milk showed higher moisture percentage than cow's milk due to high water component and total milk solid (Lai et al., 2016). The water content in goat's milk was higher compared to reference which ranged from 8090\% (Imran et al., 2008). Lower moisture content in raw cow's milk was related to the decreasing of microbial growth (Table 2) Higher moisture was detected in pasteurized milk (Table 1) which was caused by the presence of whey proteins and their hydrophilic properties which has been shown in cow's milk (Meinardi et al., 2003). While lower moisture in goat's milk was due to the presence of high precipitation of tri-calcium phosphate (Lai et al., 2016). Soliman (2005) reported that, goat's milk was less resistant to heat which one of the causes to the lower water activity and moisture content.

The protein content in milk samples was ranged from $0.74 \pm 0.45 \%$ to $2.59 \pm 0.79 \%$. Table 1 showed that the protein was increased after undergoing pasteurization process. Result showed that raw cow's milk had the lowest value of protein content and pasteurized goat's milk showed the highest value. There were significant interactions $(p<0.05)$ between animals and pasteurization towards protein content in milk. Goat's milk has high protein content because the milk was rich in casein. Hassan (2005) stated that the important components in milk were casein $(75 \%)$ and whey protein $(25 \%)$ that including lactoalbumin, lactoglobulin, serum albumin, immunoglobulin, lactoferrin and lysozyme. Due to this, the effect after undergoing pasteurization was still the same when the goat's milk was still high in protein. The protein in goat's milk was digested more readily and its constituents of amino acids were absorbed more effectively than cow's milk (Arora et al., 2013). However, for cow's milk, the decrease in protein was due to the milk presence of acid-enzyme and mixed coagulation in protein that might be occurred in milk (Malacarne et al., 2002). Studies from O'Donnell et al. (2004) stated that, low in casein in milk would lead to low abundance of protein which has shown in cow's milk. According to Lewis and Deeth (2009), pasteurization did not give major contribution for protein content in milk. Further supported by MacDonald et al. (2001), they mentioned that the protein denaturation has no impact on protein nutritional quality in milk. Law and Kolstand (1983) mentioned that LAB was able to increase their growth development when there was protein rich medium. Korhonen and Pihlanto (2007) said that, LAB would utilize the milk protein as their main source of essential and growth-stimulation amino acids.

Ash content was increased after undergoing pasteurization process. There was significant interaction $(p<0.05)$ for this content. High ash 
content in raw goat's milk was due to the presence of mineral contents like potassium and chloride in milk (Jennes, 1978). Imran et al. (2008) stated that the minerals that mostly found in ash were oxide and chloride. Pasteurized milk showed higher ash content compared to raw milk. However, the result was contradicted to previous studies whereby the concentration of minerals should be higher in raw milk (Zamberlin et al., 2012). Unfortunately, not all minerals would be affected by the heat treatment as the pasteurized milk itself could influence the content of minerals in the various milk ingredients (Abebe and Markos, 2009). Minerals were required for beneficial growth which might also include the LAB (Macleod and Snell, 1947). Some minerals like manganese would give a major contribution to the production of LAB (Raccach, 1985).

The fat content was ranged from $3.00 \pm 0.20 \%$ to $3.60 \pm 0.13 \%$. Result obtained was similar to the previous finding whereby pasteurized goat's milk would provide high fat content (Getaneh et al., 2016). There was significant difference $(p<0.05)$ between animals and treatment. In raw milk, goat's milk showed slightly higher in fat content than cow's milk which might be due to the presence of short and medium chain fatty acid that would increase the fat content in the raw milk. Xu et al., (2015) mentioned that, goat's milk was rich in fatty acid and its ability to give a better digestibility compared to cow's milk. Cerbulis et al., (2011) stated that, major fat contributions to the milk were triacylglycerols and high number of esterified fatty acids. Goat's milk has high tendency on having LAB content. Taufiq and Hadisaputro (2013) mentioned that, goat's milk has high nutritional value especially in fat content, thus it might influence the existence of LAB in milk.

Table 1 Physico-chemical content of raw and pasteurized cow's and goat's milk.

\begin{tabular}{ccccc}
\hline Analysis & RCM & RGM & PCM & PGM \\
\hline $\begin{array}{c}\text { pH } \\
\text { Moisture } \\
\text { content }\end{array}$ & $6.60 \pm 0.01^{\mathrm{b}}$ & $6.50 \pm 0.01^{\mathrm{d}}$ & $6.77 \pm 0.01^{\mathrm{a}}$ & $6.52 \pm 0.01^{\mathrm{c}}$ \\
Ash & $0.42 \pm 0.02^{\mathrm{b}}$ & $0.50 \pm 0.04^{\mathrm{b}}$ & $0.44 \pm 0.13^{\mathrm{b}}$ & $0.74 \pm 0.04^{\mathrm{a}}$ \\
Protein & $0.74 \pm 0.45^{\mathrm{c}}$ & $1.68 \pm 0.36^{\mathrm{b}}$ & $1.23 \pm 0.29^{\mathrm{bc}}$ & $2.59 \pm 0.79^{\mathrm{a}}$ \\
Fat & $3.00 \pm 0.20^{\mathrm{b}}$ & $3.20 \pm 0.21^{\mathrm{b}}$ & $3.50 \pm 0.13^{\mathrm{a}}$ & $3.60 \pm 0.04^{\mathrm{a}}$
\end{tabular}

Note: $\mathrm{RCM}=$ Raw cow's milk; RGM = Raw goat's milk; $\mathrm{PCM}=$ Pasteurized cow's milk; PGM = Pasteurized goat's milk

Each value was presented as mean \pm standard deviation $(n=3)$. Different letters were indicated for significant different $(p<0.05)$ between column.

\section{Microbiological analysis}

Total bacterial count was the highest in pasteurized milk for both ruminants (Table 2). Although raw milk contained lower bacteria, it has the possibility in having various bacterial populations (Quigley et al., 2013).

Table 2 Total bacteria, yeast and mould, and lactic acid bacteria in raw and pasteurized cow's and goat's milk.

\begin{tabular}{ccccc}
\hline Sample & RCM & RGM & PCM & PGM \\
\hline & $1.59 \pm 0.28^{\mathrm{b}}$ & $0.65 \pm 0.06^{\mathrm{c}}$ & $2.48 \pm 0.00^{\mathrm{a}}$ & $2.48 \pm 0.00^{\mathrm{a}}$ \\
& \multicolumn{4}{c}{ Total plate count } \\
& Yeast and mould \\
Analysis & $0.00 \pm 0.00$ & $0.00 \pm 0.00$ & $0.00 \pm 0.00$ & $0.00 \pm 0.00$ \\
(cfu/ml) & & Lactic acid bacteria & \\
& $2.43 \pm 0.03^{\mathrm{a}}$ & $2.41 \pm 0.03^{\mathrm{a}}$ & $2.18 \pm 0.01^{\mathrm{b}}$ & $2.11 \pm 0.09^{\mathrm{b}}$
\end{tabular}

Note: $R C M=$ Raw cow's milk; RGM = Raw goat's milk; $P C M=$ Pasteurized cow's milk; PGM = Pasteurized goat's milk

Each value was presented as mean \pm standard deviation $(n=3)$. Different letters were indicated for significant different $(p<0.05)$ between column.
Tamine and Robinson (1999) stated that, most of the bacteria that survived in pasteurized milk were known as thermoduric bacteria which might cause in high number of colonies. Thermoduric bacteria were normally consisted of gram-positive bacteria such as species from genus Enterococcus, Bacillus, Microbacterium, Micrococcus, Corynebacterium, Streptococcus and Arthrobacter (Thomas and Prasad, 2014; Murphy, 2007). Other probiotic bacteria known as LAB were also categorized as thermoduric bacteria and might increase their population. The amount of LAB in the milk would lead to the decrease in the diversity of microorganisms (Widyastuti et al., 2014). This also known as synergistic effect when LAB were able to overcome the population of microorganisms (Wedajo, 2015).

Table 2 showed that there was no interaction of milk samples towards yeast and mould. Different animals and treatments did not affect the yeast and mould count of the milk. According to Garnier et al. (2017), dairy products were less vulnerable to yeast and mould due to refrigerated storage. The low count of yeast and mould bacteria in raw milk would give major impact in pasteurized milk which helped to reduce more pathogenic bacteria (Ledenbach and Marshall, 2009). The absence of yeast and mould might be due to the inhibition by LAB (Lipińska, 2016).

Higher LAB colonies were detected in raw milk compared to pasteurized milk. This result was similar to study by Bluma and Ciprovica (2015). Raw milk was reported to be rich with variety of LAB (Wassie and Wassie, 2016; Azhari Ali, 2011). The existence of LAB in pasteurized milk was indicated for the high stability of LAB against high temperature due to its thermoduric properties (Carminati et al., 2014). This property was really important for the LAB to be developed as the starter culture for any fermented product.

\section{API ZYM test}

API ZYM was used to identify the enzyme profile of different lactic acid bacteria in milk samples (Stoyanovski et al., 2013). The enzyme presence has introduced the potential LAB in milk samples. Different enzymes have been detected in different strains of LAB in different samples (Table 3). This showed that there was interaction between conditions of the sample, either due to the difference of available macronutrients or heating treatments. Higher macronutrients were found in pasteurized milk (Table 1) which might also help in the survival of LAB in pasteurized milk. Table 3 showed different types of enzyme profile by lactic acid bacteria isolated from different samples. The enzyme profile could be used to assume the potential type of LAB in the sample (Humble et al., 1977).

Table 3 Enzyme activities of lactiç acid bacteria isolates grown on MRS agar as determined by the API ZYM reactions.

\begin{tabular}{|c|c|c|c|c|}
\hline \multirow[t]{2}{*}{ ENZYME ASSAY FOR } & \multicolumn{4}{|c|}{ SAMPLE } \\
\hline & $\mathbf{R C M}$ & RGM & PCM & PGM \\
\hline Control & + & + & + & + \\
\hline Alkaline phosphatase & - & - & - & - \\
\hline Esterase (C4) & - & - & - & + \\
\hline Esterase Lipase (C8) & - & + & + & + \\
\hline Lipase (C14) & - & - & - & - \\
\hline Leucine arylamidase & - & + & + & + \\
\hline Valine arylamidase & - & + & + & + \\
\hline Cystine arylamidase & - & - & + & + \\
\hline Trypsin & - & - & + & + \\
\hline a-chymotrypsin & - & - & + & + \\
\hline Acid phosphatase & - & + & + & + \\
\hline Naphtol-AS-BI-phosphohydrolase & - & + & + & + \\
\hline$\alpha$-galactosidase & - & - & - & - \\
\hline$\beta$-galactosidase & - & - & - & - \\
\hline$\beta$-glucuronidase & - & - & - & - \\
\hline a-glucosidase & - & - & + & + \\
\hline$\beta$-glucosidase & - & - & + & + \\
\hline $\mathrm{N}$-acetyl- $\beta$-glucosaminidase & - & - & + & + \\
\hline a-mannosidase & - & - & - & - \\
\hline$\alpha$-fucosidase & - & - & - & - \\
\hline
\end{tabular}

Note: $R C M=$ Raw cow's milk; RGM = Raw goat's milk; PCM = Pasteurized cow's milk; $P G M=$ Pasteurized goat's milk. 
Different enzyme activities were showed by different samples (Table 3). Most of the enzymes produced by the LAB strain were leucine arylamidase, valine arylamidase, cystine arylamidase, trypsin, $\alpha$-chymotrypsin,naphthol-AS-BI-phosphohydrolase, $\alpha$-glucosidase, $\beta$ glucosidase and acid phosphatase. All of these enzymes have different characteristics that indicated to the different stability between strains of LAB. More enzyme activities of LAB were shown by pasteurized milk. The difference was related to the type of animals and also heat treatments. Higher enzyme activity in pasteurized milk was indicated to the thermal stability by the LAB. In contrast, lower activity in raw milk could be due to the synergestic effect between other aerobic bacteria and LAB. The diverse type of enzyme by LAB might influence the composition and taste in food (Patel et al., 2013; Stoyanovski et al., 2013).

\section{CONCLUSION}

The purpose of this study was to study the effect of pasteurization on the stability of lactic acid bacteria (LAB) in milk. Goat and cow's milk were tested to see if is there any interaction between different types of animals. The existence of LAB was also studied to see the correlation between the macronutrients in the milk. Other general microorganisms were tested to see if their existences would create a synergestic condition towards the LAB growth. Study showed that raw milk of both animals contained slightly higher LAB compared to pasteurized milk. Lower count of total bacterial growth was also detected in the raw milk which might be the result of synergestic effect between both aerobic bacteria and LAB in the milk. No yeast and mold were detected in all samples which might due to the inhibition properties by LAB. Higher macronutrients (proximate composition) in pasteurized milk could be considered as one of the factors for the survival of LAB against pasteurization temperature. By using API ZYM assay kit, all of the LAB strains showed different enzyme activities. Most of the enzymes produced by the $\mathrm{LAB}$ strain were leucine arylamidase, valine arylamidase, cystine arylamidase, trypsin, $\alpha$-chymotrypsin, naphtholAS-BI-phosphohydrolase, $\alpha$-glucosidase, $\beta$-glucosidase and acid phosphatase. All of these enzymes showed different characteristics that indicated to the different stability between strains of LAB.

\section{REFERENCES}

Abdul Elrahman, S. M. A., Ahmed, A. M. E. M. S., El Zubeir, I. E. M., El Owni, O. A. O., Ahmed, M. K. A. 2013. Effect of storage temperature on the microbiological and physicochemical properties of pasteurized milk. Annals. Food Sci. Technol. 14, 1-7.

Abebe, T., \& Markos, T. 2009. Milk quality control. International Center for Agricultural Research in the Dry Areas (ICARDA). Technical Bulletin No. 2.

Anderson, M., Hinds, P., Hurditt, S., Miller, P., McGrowder, D., AlexanderLindo, R. 2011. The microbial content of unexpired pasteurized milk from selected supermarkets in a developing country. Asian Pac. J. Trop. Biomed. $1,205-211$.

Arora, R., Bhojak, N., \& Joshi, R. 2013. Comparative aspects of goat and cow milk. Int. J. Eng. Sci. Invent. 2(1), 7-10.

AOAC. 2000. Official Methods of Analysis of AOAC International, 17th edition. The Association of Official Analytical Chemists. Gaithersburg, MD, USA.

Azhari Ali, A. 2011. Isolation and identification of lactic acid bacteria from raw cow milk in Khartoum State, Sudan. Int. J. Dairy Sci. 6(1), 66-71.

Azizkhani M., \& Tooryan F. 2017. Chemical and microbial quality of Iranian commercial pasteurized milk samples at their expiration date. J Food Qual Hazards Control. 4(2), 53-57.

Balthazar, C. F., Pimentel, T. C., Ferrão, L. L., Almada, C. N., Santillo, A., Albenzio, M., Mollakhalili, N., Mortazavian, A. M., Nascimento, J. S., Silva, M. C., Freitas, M. Q., Sant'Ana, A. S., Granato, D., Cruz, A. G. 2017. Sheep milk: Physicochemical characteristics and relevance for functional food development. Compr Rev Food Sci Food Saf. 16(2), 247262.

Blagojev, N., Skrinjar, M., Veskovic-Moracanin, S., \& Soso, V. 2012. Control of mould growth and mycotoxin production by lactic acid bacteria metabolites. Rom Biotechnol Lett. 17(3). 7219-7226.

Bluma, A., \& Ciprovica, I. 2016. Non starter lactic acid bacteria in raw milk thermally treated milk and swiss type cheese. Res. Rural Dev. 1, 98-101.
Brock, T. D., \& Madigan, M. T. (1988) Biology of microorganisms (5th Edition), Prentice Hall, Englewood Cliffs, N.J.

Wiegel, J. 1990. Temperature soans for growth: hypothesis and discussion. FEMS Microbiol. Rev. 75(2-3), 155-169

Caprita, A., Caprita, R. and Cretescu, I. 2014. The effects of storage conditions on some physicochemical properties of raw and pasteurized milk. $J$. Agroaliment. Processes Technol. 20(2), 198-202.

Carminati, D., Tidona, F., Fornasari, M. E., Rossetti, L., Meucci, A., \& Giraffa G. 2014. Biotyping of cultivable lactic acid bacteria isolated from donkey milk. Lett Appl Microbiol. 59, 299-305.

Cerbulis, J., Park, O. W., \& Farrell, J. R. 1982. Composition and distribution of lipids of goats milk. J. Dairy Sci. 65, 2301-2307.

Chipilev, N., Daskalov, H., Stoyanchev, T. 2016. Study on the prevalence of lipolytic yeasts and moulds in raw cow milk and white brined cheese. Bulg. J. Vet. Med. 19(2), 117-126.

Claeys, W. L., Cardoena, S., Daubeb, G., Blockc, J., Dewettinckd, K., Dierick, K., Zutter, L., Huyghebaert, A., Imberechts, H., Thiange, P. 2013. Raw or heated cow milk consumption: Risks and benefits. Food Control. 31(1), 251-262.

Dalie, D. K. D., Deschamps, A. M., Forget, F. R. 2010. Lactic acid bacteria Potential for control of mould growth and mycotoxins. Food Control. 21(4), 370-380.

de Vrese, M., Stegelmann, A., Richter, B., Fenselau, S., Laue, C., Schrezenmeir, J. 2001. Probiotics--compensation for lactase insufficiency. Am. J. Clin. Nutr. 73(2), 421- 429.

Delavenne, E., Mounier, J., Déniel, F., Barbier, G., Le Blay, G. 2012. Biodiversity of antifungal lactic acid bacteria isolated from raw milk samples from cow, ewe and goat over one-year period. Int. J. Food Microbiol. 155(3), 185-190.

Dumalisile, P., R. Witthuhn, T. Jbritz. 2005. Impact of different pasteurization temperatures on the survival of microbial contaminants isolated from pasteurized milk. Int. J. Dairy Technol. 58(2): 74-82.

FAO. 2013. Milk and dairy products in human nutrition. In: Muehlhoff, E., Bennette, A. McMahon, D. (Eds). Food and Agriculture Organization of the United Nations, Rome.

Garnier, L., Valence, F. and Mourier, J. 2017. Diversity and control of spoilage fungi in dairy products: An update. Microorganisms. 5(3), 42.

Getaneh G, Mebrat A, Wubie A, Kendie H. 2016. Review on goat milk composition and its nutritive value. J. Nutr. Health Sci. 3(4), 1-10.

Hassan, R. A., El Zubeir, I. E. M., Babiker, S. A. 2007. Effect of pasteurization of raw camel milk and storage temperature on the chemical composition of fermented camel milk. Int. J. Dairy Sci. 2(2), 166-171.

Humble, M. W., King, A., Phillips, I. 1977. API ZYM: A simple rapid system for the detection of bacterial enzymes. J. Clin. Pathol. 30(3), 275-277.

Hutkins, R.W., Nannen, N. L. 1993. pH homeostasis in lactic acid bacteria. $J$. Dairy Sci. 76(8), 2354-2365.

Imran, M., Khan, H., Hassan, S. S., Khan, R. 2008. Physicochemical characteristics of various milk samples available in Pakistan. J Zhejiang Univ Sci B., volume 9 (7), 546-551.

Jenness, P. E. 1978. The nutritive value of dairy products. Dairy Industries Int. 43, 7-16.

John, C. B. 1996. A summary of titratable acidity [Internet]. The Dairy Research and Information Center (DRINC). The University of California. Retrieved from DRINC website: https://drinc.ucdavis.edu/dairy-foodsciences/summary-titratable-acidity

Khedid, K., Faid, M., Mokhtari, A., Soulaymani, A., Zinedine, A. 2009. Characterization of lactic acid bacteria isolated from the one humped camel milk produced in Morocco. Microbiol Res. 164(1), 81-91.

Korhonen, H., \& Pihlanto, A. 2007. Bioactive peptides from food proteins. In: Hui, Y. H. (Ed) Handbook of Food Products Manufacturing. Publisher, Place Published, pp. 5-38.

Lai, C. Y., Fatimah, A. B., Mahyudin, N. A., Saari, N., Zaman, M. Z. 2016. Physico-chemical and microbiological qualities of locally produced raw goat milk. Int. Food Res. J. 23(2), 739-750.

Law, B. A., and Kolstad, J. 1983. Proteolytic systems in lactic acid bacteria, Antonie Van Leeuwenhoek. 49(3), 225-245.

Ledenbacch, L. H., Marshall, R. T. 2010. Microbiological spoilage of dairy products Compendium of the microbiological spoilage of foods and beverages. Springer. 41-67 In: Sperber W., \& Doyle, M. (Eds) Compendium of the Microbiological Spoilage of Foods and Beverages. Food Microbiology and Food Safety. Springer, New York, NY, pp. 41-67.

Lewis, M. J., \& Deeth, H. C. 2009. Heat treatment of milk. In: Tamime, A. Y. (Ed.) Blackwell Publishing Ltd. UK. p.168 Milk processing and quality management. Society of Dairy Technology book series. Wiley-Blackwell, Oxford, pp. 168-204.

Lipińska, L. Klewick, R., Klewicka, E. Kołodziejczyk, K., Sójka, M., Nowak, A. 2016. Antifungal activity of Lactobacillus sp. bacteria in the presence of xylitol and galactosyl-xylitol. BioMed Res. Int. Article ID 5897486, 8 pp. 
MacDonald, L. E., Brett, J., Kelton, D. 2001. A systematic review and metaanalysis of the effects of pasteurization on milk vitamins, and evidence for raw milk consumption and other health-related outcomes. J. Food Prot. 74(11), 1814-1832.

Macleod, B. Y. R. A., Snell, E. E. 1947. Some mineral requirement of the lactic acid bacteria. J. Biol. Chem. 170, 351-365

Malacarne, M., Martuzzi, F., Summer, A., Mariani, P. 2002. Protein and fat composition of mare's milk: Some nutritional remarks with reference to human and cow's milk. Int. Dairy J. 12(11), 869-877.

Meinardi, C. A., Zalazar, C. A., Hynes, E. R., Candiotti, M. C., 2003. Incremento del rendimeinto del queso cremoso argentino por tratamiento de la leche a temperaturas y tiempos superiores a los de pasteurización. Argentine Journal of Lactology, Revista Argentina de Lactología. 22, 4554.

Burgess, K. 2013. Milk and dairy products in human nutrition. Int. J. Dairy Technol. 67, 303-304.

Murphy, S. C. 2007. The laboratory pasteurization counts [Notes]. Dairy Food Science Notes. Cornell University. Retrieved from https://foodsafety. foodscience.cornell.edu/sites/foodsafety.foodscience.cornell.edu/files/share d/documents/CU-DFScience-Notes-Bacteria-Thermoduric-04-08.pdf

O’Donnell, R., Holland, J., Deeth, H., Alewood, P. 2004. Milk proteomics. Int. Dairy J. 14(12), 1013-1023.

Ogola, H., Shitandi, A., and Nanua, J., 2007. Effect of mastitis on raw milk composition quality. J. Vet. Sci. 8(3), 237-242

Quigley, L., O'Sullivan, O., Stanton, C., Beresford, T. P., Ross, R. P., Fitzgerald, G. F., Cotter, P. D. 2013. The complex microbiota of raw milk, FEMS Microbiol. 37(5), 664-698.

Patel, A., Shah, N., Prajapati, J.B. 2013. Biosynthesis of vitamins and enzymes in fermented foods by lactic acid bacteria and related genera. Crop J. Sci. Technol. 5(2), 85-91.

Raccach, M. 1985. Manganese and lactic acid bacteria. J. Food Prot. 48(10), 895-898.

Samarzija, D., Zamberlin, S., Pogacic, T. 2012. Psychotropic bacteria and milk and dairy products quality, Mljekarstvo/Dairy. 62(2), 77-95. Retrieved from https://hrcak.srce.hr/file/124020

Soliman G. Z. A. 2005. Comparison of chemical and mineral content of milk from human, cow, buffalo, camel and goat in Egypt. Egypt J Hosp Med. 21, 116-130.
Stoyanovski, S., Gacoviski, Z., Antonova-Nikolova, A., Kirilow, N., Ivanova, I., Tenev, T., Hadjinesheva, V. 2013. API ZYM enzymatic profile of lactic acid bacteria isolated from traditional Bulgarian meat products "Lukanka". Bulg. J. Agric. Sci. 19(2), 86-89.

Tamine, A. Y., Robinson, R. K. 1999. Yoghurt: Science and Technology. Woodhead Publication, Cambridge, England.

Taufiq, T.T., Hadisaputro, W. 2013. Fermented goat milk and cow milk produced by different starters of lactic acid bacteria: Quality studies. J. Agric. Sci. Technol. 3, 904-911.

Tesfay, T., Kebede, A., and Seifu, E. 2015. Physico chemical properties of cow milk produced and marketed in Dire Dawa Town, Eastern Ethiopia. Food Sci. Qual. Manag. 42, 56-61.

Teshome, G. 2015. Review on lactic acid bacteria function in milk fermentation and preservation. Afr. J. Food Sci. 9(4), 170-175.

Thomas, A., \& Prasad, V. 2014. Thermoduric bacteria in milk - A review. Int. J. Sci. Res. 3(6), 2438-2442.

Troller, J. A., \& Stinson, J. V. 1981. Moisture requirements for growth and metabolite production by lactic acid bacteria. Appl. Environ. Microbiol. 42(4), 682-687.

USDA. 2012. Introduction to the Microbiology of Food Processing. Food Safety and Inspection Service, United States Department of Agriculture. Small Plant News Guidebook Series, Washington, D.C.

Wanjala, G. W., Mathooko, F. M, Kutima, P. M., and Mathara, J. M. 2017 Microbiological quality and safety of raw and pasteurized milk marketed in and around Nairobi region. Afr. J. Food Agric. Nutr. Dev. 17(1), 1151811532.

Wassie, M. \& Wassie, T. 2016. Isolation and identification of lactic acic bacteria from raw cow milk. Int. J. Adv. Res. Biol. Sci. 3(8), 44-49.

Wedajo B. 2015. Lactic acid bacteria: Benefits, selection criteria and probiotic potential in fermented food. J. Prob. Health. 3, 129.

Widyastuti, Y., Febrisiantosa, R, A. 2014. The role of lactic acid bacteria in milk fermentation, Food Nutr. Sci. 5(4), 435-442.

Xu, M., Wang, Y., Dai, D., Zhang, Y., Li, Y., and Wang, J. 2015. Comparison of growth and nutritional status in infants receiving goat milk based formula and cow milk based formula: A randomized, double-blind study. Food Nutr. Res. 59, 28613.

Zamberlin, S., Antunac, N., Havranek, J., Samar Zija, D.2012. Mineral elements in milk and dairy products. Mljekarstvo. 62(2), 111-125. 